\title{
FACTORS RELATED TO BREASTMILK PRODUCTION ON POSTPARTUM MOTHERS IN EAST PONTIANAK, WEST KALIMANTAN
}

\author{
Otik Widyastutik $^{1}$, Yuwan Chartasim ${ }^{1}$, Elly Trisnawati ${ }^{1}$, Selviana ${ }^{1}$ \\ ${ }^{1}$ Public Health Study Program, \\ Pontianak Muhammadiyah University, Pontianak, Kalimantan Barat, Indonesia \\ Corresponding address: Otik Widyastutik \\ Email: otik@unmuhpnk.ac.id
}

\begin{abstract}
Producing breastmilk is a mother's ability for the next six weeks after giving birth. Based on data from the Health Office of Pontianak City, exclusive breastfeeding coverage is 25\% in East Pontianak District. A preliminary study conducted in East Pontianak Sub district, seven out of ten respondents who underwent breastfeeding, their breastmilk was not running well. There are $70 \%$ of babies experienced weight increment below 500 grams/month. In addition, $70 \%$ mothers drinking less than twelve glasses/day, $70 \%$ mothers do not receive support from their husbands in breastfeeding process, $60 \%$ mothers have never been exposed to breastfeeding information, and 50\% mothers experienced moderate anxiety levels after giving birth. The research aimed to determine the determinants of postpartum mother's milk production in East Pontianak District. This research is observational research with a cross-sectional approach, and the research subject is 48 postpartum mothers. The results showed that the determinant factor could be seen from the relationship of fluid intake ( $p$-value $=0.000)$, husband's support ( $\mathrm{p}$-value $=0.000)$, information exposure $(p$-value $=0.010)$, supplement $(p$-value $=0.000)$, and energy intake $(p$ value $=0.000$ ), to breast milk production. Recommendations addressed to the community health center such as work more active in providing counselling, activating cadres by providing practices. Therefore, they can assist in providing knowledge about breastfeeding and making creative promotional media.
\end{abstract}

Keywords : breast milk production, postpartum, nutrition intake

\section{INTRODUCTION}

Regarding the Sustainable Development Goals (SDGs) 2030, breastfeeding is one of the first steps for a prosperous human being. Providing exclusive breastfeeding has a role to prevent hunger and malnutrition, improving the development of mental, babies' cognitive, and reduce the number of death of children. The successful achievement of giving exclusive breastfeeding needs goodwill, sincerity, commitment, and determination of the mother to always take into consideration the procedure how to blush, storing and giving pumped breastmilk (Salamah and Prasetya, 2019).

In 2015, the mortality rate of infants in the world was approximately 4.5 million cases, as much as $75 \%$ of them aged less than five years. Results of the Survey of Demography and Health of Indonesia (IDHS) 2017 figure showed infant mortality rate (IMR) 
is 24 death per 1,000 births alive. It means one of 42 children died prior to year one (Rahmayanti, 2018). The high neonatal mortality rate (IMR) will affect 59\% of infant mortality. The high death of infants is due to vulnerability to disease. One of the efforts to prevent a baby's mortality is by providing breast milk to a newborn baby. In 2018, World Health Organization recommended that newly born infants be given breastmilk until the age of six months without any foods or liquids, except for vitamins, minerals, drugs that have been permitted for any reason a medical and could continue giving breast milk until the age of two annually (Indonesian Ministry of Health, 2018).

West Kalimantan province occupies ratings to four the lowest percentage of achievement Award breastfeeding exclusively, namely by $28 \%$, the target of the strategic plan of the year 2018 amounted to 37.3\% (Riskesdas, 2018). Based on the data in 2018 in West Kalimantan percentage of coverage breastfed exclusively supreme in Melawi Regency at $74.19 \%$ and the lowest in Landak Regency at $24.13 \%$, while in the city of Pontianak it was ranked nine with the lowest percentage of exclusive breastfeeding coverage which was 59.89\% (West Kalimantan, 2018).

Breastmilk production is the mother's ability to produce breast milk to meet the baby needs. Breastmilk production is the process of releasing breastmilk. Giving breastmilk is an interaction that is significantly complex between stimuli mechanics, nerve and hormone (Kurniati, Marsinova Bakara and Susanti, 2019). A sufficient breastmilk takes place if the babies' weight grows to 500 grams per month or 125 grams per week (Yanti, Yohanna and Nurida, 2018).

Several factors influence breastmilk production, both the direct (behavioral breastfeeding, psychological mother) or indirect (social-cultural and baby, which will affect the psychological mother). Furthermore, the other factor is the baby's ability to suck. A healthy baby can empty one breast about 5-7 minutes and the milk in the baby's stomach will be empty in two hours. The previous study explains that giving breastfeed the babies is unnecessarily scheduled. It will be on babies' demand. The often to provide the breastfeed, the better the breastmilk will come out. Limitations subjected to the schedule in undertaking breastfeeding will influence babies' sucking movement and breast milk production (Senewe, Rompas and Lolong, 2017). Postpartum is the period after childbirth which lasted for six weeks. During this period, lactation occurs, which is the whole process of breastfeeding, starting from breast milk production to the operation of the baby sucking and swallowing breast milk. The period of lactation has a purpose, namely to increase the provision of breastfeeding exclusively and continue giving breast milk to 
children age two (Bogen and Whalen, 2019).

Based on the preliminary study of the Public Health Center in East Pontianak district, seven out of ten respondents who experienced breastmilk production suffer the impediment. $70 \%$ of infants experienced a weight increase fewer than 500 grams per month. It is due to several things: the intake of fluid in the capital, $70 \%$ of the ten mothers drank less than $3000 \mathrm{ml}$ in a day. The $70 \%$ of respondents did not receive a husband's support in giving breast milk. $60 \%$ of respondents were unexposed to information about breastfeeding indirectly / through the media. Therefore, based on the background above, the researchers focused on such topic "Factors Associated with Breastmilk Production Post Maternity in Public Health Center District of East Pontianak (Saigon)".

\section{METHOD}

This research was observational with Cross-Sectional approach. The background of the research is Public Health Center (Puskesmas) District of Pontianak East in September 2019. The research population is a mother who is still in the postpartum period in Public Health Center (Puskesmas) District of East Pontianak (Saigon). The period in July - August 2019 of 48 people. Samples in this research are mothers, able to communicate well and still in the postpartum period. The sampling was the total sampling with 48 mothers post childbirth. The exclusion sample criteria was postpartum mother who did not breastfed her baby since the birth of the baby. However, no mothers has excluded from this research.

The data collection was undertaken using interviews, questionnaires, and observation. Then the data is recorded systematically to discover the factors that affect the production of breastfeeding after childbirth. Data analysis used univariate and bivariate with chi-square test and 95\% confidence level.

There are five characteristics of respondents: the mother's age, husband's age, mother's occupation, husband's occupation and income. Meanwhile, the main variables in this study which were analyzed univariately and bivariate were fluid intake, husband's support, information exposure, supplement intake and energy intake, and milk production. Data collection was undertaken using a questionnaire consisting of open-ended questions. Breastmilk production variables were collected through a questionnaire consisting of eight questions that had been tested for validity and reliability. Variables of fluid intake, supplement intake, and information exposure used openended questions consisting of 1 - 2 questions. Energy intake variables were collected through a semiquantitative FFQ questionnaire. While the husband's support variable used a questionnaire consisting of 5 questions that had 
been tested for validity and reliability. The dependent variable in this study was milk production, while the independent variables were fluid intake, husband's support, information exposure, supplement intake, and energy intake. The dependent variable is milk production, measured based on current and non-current standards. It is said to be smooth if 6 out of 8 question items are stated accordingly. Independent variables were measured using a self-made questionnaire through selfdevelopment, with validity and reliability tests. The validity and reliability tests of the question instruments were undertaken from 30 different respondents out of 48 samples. The results of the instrument validity test showed that all questions used to measure the variable milk production (8 questions) were valid, provided that $\mathrm{r}$-count was greater than $\mathrm{r}$-table $(\mathrm{n}=$ 30; r-table $=0.361)$. Likewise, with the Cronnbach Alpha reliability test, the value was 0.685 , which was greater than 0.600 (the standard used). Therefore, all question items in the variable of milk production were inconsistent. As for the husband's support variable (5 questions), all question items were proven to be valid, provided that $\mathrm{r}$ count was greater than $\mathrm{r}$-table $(\mathrm{n}=$ 30; r-table $=0.361$ ). The Cronnbach Alpha value was 0.692 , greater than 0.600 (the standard used). Therefore, that all question items in the husband support variable can be said to be consistent. The range of validity for the variable milk production was $0.428-0.724$, while the value for the husband's support variable was $0.591-0.786$. Chisquare test was used for bivariate analysis using the statistical product and service solution (SPSS) 24.0 for Mac, with a significance of $\mathrm{P}<0.05$. Breastmilk production comes out through the nipples, and the breasts will feel tense if you have enough breastmilk. Usually, the baby will fall asleep three to four hours after breastfeeding. Babies will urinate six to eight times a day with clear yellow urine. Babies will defecate three to four times a day. Babies suckle 8-10 times within twentyfour hours. Babies will gain at least 500 grams per month. An interview with a questionnaire instrument was undertaken to collect data. If the answer is 'breastmilk production is impeded', then a score of one will be given. If the milk production is smooth, then a score of two will be given (Indonesian Ministry of Health, 2013).

Fluid intake is the average amount of fluid drunk by the mother for 24 hours in a $250 \mathrm{ml}$ glass. The collection of fluid intake data was carried out by interview using a questionnaire and measuring cup. The result of measurement for this variable is represented by scoring. Mothers who drink less than twelve glasses per day are equal to one. In contrast, mothers who drink more significant than 12 glasses per day are similar to two (Indonesian Ministry of Health, 2013)

Husband or family support is obtained from interviews using a questionnaire. The measurement 
results state that if the answer is less supportive or the answer is "yes" less than four, then a score of one is given, whereas if the "yes" answer is greater than or equal to four, then a score of two is provided.

Information exposure about breastfeeding is information that has been obtained by mothers either directly communicating or from the media (print, electronic, online). Measurement results were obtained from interviews using a questionnaire. If the answer is 'unexposed to information', then a score is given.

Vitamin A supplement is given to breastfeeding mothers during the puerperium that has significant benefits for both mother and baby. Measurement results were obtained from interviews using a questionnaire instrument. If the answer does not take vitamin A supplements, then a score of one is given, while the mother who says yes consumes vitamin A and others, will be given a score of two.

Vitamin A is one of the most crucial intakes as it plays an important role and determines mothers' breastfeeding success. The measurement results were obtained from interviews using the FFQ (food frequency questionnaire) questionnaire. If the energy intake is less than $2250 \mathrm{cal}$ per day, then a score of one is given, whereas if the energy intake is greater equal to 2250 cal per day, then a score of two is presented.

Protein intake was an additional protein needed to produce breast milk. This variable was measured using interviews using the FFQ questionnaire instrument (food frequencies questionnaire). If protein intake was less 20 grams per day, then a score of one was given, whereas if protein intake was greater equal to 20 grams per day, then a score of both was provided.

Fat intake was an energy reserve to produce breast milk. This variable was measured using an interview using the FFQ (food frequency questionnaire) questionnaire. If the fat intake was less than 11 grams per day, then a score of one was given, whereas if the fat intake was $\geq 11$ grams/day, then a score of both was provided.

FFQ method assessed the relationship between the intake of certain foods and certain nutrients' content to the risk of disease events. FFQ was not intended to determine nutrient intake alone but is more specically to determine the correlation between exposure to certain foods and malnutrition incidence. Exposure to nutrient intake for a long time has implications for general health conditions. If the result of exposure to unbalanced nutrient intake is chronic, then clinical symptoms of nutritional disorders (pathological conditions) will occur (Sirajuddin, Surmita and Astuti, 2018)

FFQ form used in the consumption survey was the one that has gone through standardized preparation stages. FFQ form stipulated nine options for FFQ method: the choice of the frequency of meals, namely how many times 
per proportion a day, how many times per balance a week, how many times per a month, how many times per balance a year, never. The researchers were using food catalogue to carry out the consumption survey using the FFQ

\section{RESULTS}

This study illustrated the respondents' characteristics and all the variables by tables. All data method. It may overcome the language barrier between the respondent and the interviewer. Nomor Keterangan Kelaikan Etik ("Ethical Clearance"): 014/KEPKFIKES/KET/2019

presented will be essential to be used as material for discussion in this study. As can be seen from table number 1 until table number 3 below:

Table 1. Characteristic frequency distribution of research respondents

\begin{tabular}{lll}
\hline Respondent characteristic & Frequency (n) & Percentage (\%) \\
\hline Mother's age & & \\
<25 years & 18 & 37.5 \\
$\geq 25$ years & 30 & 62.5 \\
\hline Husband's age & & \\
$<25$ years & 6 & 12.5 \\
$\geq 25$ years & 42 & 87.5 \\
\hline Mother's type of work & & \\
Private & 9 & 18.7 \\
Civil servants & 6 & 6.3 \\
Teacher & 3 & 12.5 \\
Housewives & 30 & 62.5 \\
Husband's type of work & & \\
Private & 33 & 68.7 \\
Civil servants & 7 & 14.6 \\
Teacher & 8 & 16.7 \\
\hline Income & & \\
$<2,300,000$ & 9 & 18.6 \\
$\geq 2,300,000$ & 39 & 81.4 \\
\hline Total & 48 & 100 \\
\hline
\end{tabular}

Based on the table 1 above, from 48 respondents obtained the average age of the mother $\geq 25$ years was higher $(62.5 \%)$. Similar to the average age of husbands $\geq 25$ years, there were $42(87.5 \%)$ respondents higher than under 25. Based on the type of work of the mother, mostly mothers be a house wife $(62.5 \%)$. 
Table 2. The frequency distribution of the univariate analysis result study

\begin{tabular}{lcc}
\hline Respondent Characteristics & Frequency (N) & $\begin{array}{l}\text { Percentage } \\
(\%)\end{array}$ \\
\hline Energy intake & & 72,9 \\
\hline Less & 35 & 27,1 \\
\hline Enough & 13 & \\
\hline Fluid intake & 28 & 58,3 \\
\hline Less & 20 & 41,7 \\
\hline Enough & & \\
\hline Vitamin A intake & 29 & 60,4 \\
\hline Less & 19 & 39,6 \\
\hline Enough & & \\
Exposure to Information & 31 & 64,6 \\
About Breastmilk & 17 & 35,4 \\
No & & 35,4 \\
Yes & 17 & 64,6 \\
\hline Husband support & 31 & \\
Yes & & 62,5 \\
\hline No & 30 & 37,5 \\
\hline Breastmilk Production & 18 & \\
\hline Not smooth &
\end{tabular}

Mostly, occupation of the respondent's husband was private sector $(68.7 \%)$. The average income of a family that was > Rp.2.300.00 $(81.4 \%)$. Table above showed that the proportion of respondents who consume intake of energy less over a lot that was 35 people $(72.9 \%)$ compared to enough energy intake that for $13(27.1 \%)$.

Based on Table 3, it was found that the proportion of respondents that the intake of liquid was less than 12 cups per day tend to experience un-smooth production of breast milk (92.9\%) was larger than the respondents that the intake of fluid greater equal to 12 cups per day $(20 \%)$. Statistical test Chisquare shows the significance of $\mathrm{p}$ value $=0.000>0.05$ means that there was a relationship between the intake of fluids and the production of breastfeeding mothers after childbirth. The analysis results obtained by value $\mathrm{PR}=4.643$ implies that the prevalence of events un-smooth production of breast milk group intake of liquids less than 12 cups per day was larger than the prevalence un-smooth production of breast milk group intake of fluids greater and equal to 12 cups per day. 
Table 3. The frequency distribution of the bivariate analysis result study

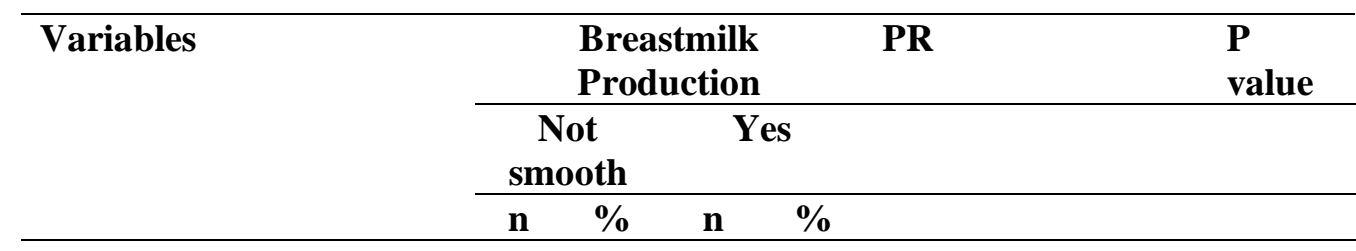

Fluid Intake

\begin{tabular}{|c|c|c|c|c|c|c|c|}
\hline$<12$ glasses & 26 & $\begin{array}{c}92 . \\
9\end{array}$ & 2 & 7.1 & \multirow[t]{2}{*}{$\begin{array}{l}4.643 \\
11.222)\end{array}$} & \multirow{2}{*}{\multicolumn{2}{|c|}{$(1.921-\quad 0.000$}} \\
\hline$\geq 12$ glasses & 4 & 20 & 16 & 80 & & & \\
\hline \multicolumn{8}{|c|}{ Husband's Support } \\
\hline No & 28 & $\begin{array}{c}90 . \\
3\end{array}$ & 3 & 9.7 & \multirow[t]{2}{*}{$\begin{array}{l}7.677 \\
28.366)\end{array}$} & \multirow[t]{2}{*}{$(2.078-$} & 0,000 \\
\hline Yes & 2 & $\begin{array}{c}11 . \\
8\end{array}$ & 15 & $\begin{array}{c}88 . \\
2\end{array}$ & & & \\
\hline
\end{tabular}

Exposure to Information

About Breastmilk

\begin{tabular}{|c|c|c|c|c|c|c|}
\hline No & 24 & $\begin{array}{c}77 . \\
4\end{array}$ & 7 & $\begin{array}{c}22 . \\
6\end{array}$ & $2.194(1.121-4.292)$ & 0,006 \\
\hline Yes & 6 & $\begin{array}{c}35 . \\
3\end{array}$ & 11 & $\begin{array}{c}64 . \\
7\end{array}$ & & \\
\hline \multicolumn{7}{|c|}{ Vitamin A intake } \\
\hline No & 28 & $\begin{array}{c}96 . \\
6\end{array}$ & 1 & 3.4 & $\begin{array}{l}9.172 \quad(2.468- \\
34.088)\end{array}$ & 0.000 \\
\hline Yes & 2 & $\begin{array}{c}10 . \\
5\end{array}$ & 17 & $\begin{array}{c}89 . \\
5\end{array}$ & & \\
\hline \multicolumn{7}{|l|}{ Energy } \\
\hline Less & 28 & 80 & 7 & 20 & $\begin{array}{l}5.200(1.438- \\
18.807)\end{array}$ & 0.000 \\
\hline Enough & 2 & $\begin{array}{c}15 . \\
4\end{array}$ & 11 & $\begin{array}{c}84 . \\
6\end{array}$ & & \\
\hline
\end{tabular}

The proportion of respondents who did not get the support of husbands tend to experience unsmooth production of breast milk (90.3\%) was large compared with respondents who got the husband support (11.8\%). Test results statistics obtained p-value $=0.000$ > 0.05 mean a significant relationship between husband support and breastfeeding mothers' production after childbirth. The results of the analysis obtained a value PR = 7.677. That means the prevalence of events un-smooth production of breast milk in the group that did not receive the support of husband, and 7.677 was enormous compared with the prevalence of un-smooth production of breast milk in the group get the support of her husband.

The proportion of respondents who did not get information about 
breastfeeding were likely to experience un-smooth production of breast milk $(77.4 \%)$ is large compared with respondents who get information about breastfeeding (35.3\%). Test results statistics obtained p-value $=0.000>0.05$ mean a significant relationship between husband support and breastfeeding mothers' production after childbirth. The results of the analysis obtained by value $\mathrm{PR}=$ 7.677. It means that the prevalence of events un-smooth production of breast milk in the group that did not receive the support of husband, and 7.677 was enormous compared with the prevalence un-smooth production of breast milk in the group who get the support of her husband.

The proportion of respondents who did not get the intake of supplements tended to experience un-smooth production of breast milk $(96.6 \%)$ was large compared with respondents who get the input of supplements (10.5\%). Test results statistics obtained $p$-value $=$ $0.000>0.05$ mean a relationship between breastfeeding exposure and breastfeeding mothers' production after childbirth. The results of the analysis obtained by value PR = 2.194 . It means that the prevalence of events un-smooth production of breast milk in the group that did not receive information about breastfeeding 2,194 larger than the prevalence of un-smooth production of breast milk in the group who get information about breastfeeding.

The proportion of respondents whose energy intake was less likely to experience non- smooth production of breast milk (80\%) was greater than that of respondents whose energy intake was sufficient (15.5). The statistical tests result obtained $\mathrm{p}$-value $=0.000>0.05$ mean a relationship between energy consumption and breastfeeding mothers' production after childbirth. The analysis results obtained by value $\mathrm{PR}=5.200$ mean that the prevalence of events un-smooth production of breast milk in the group that the intake of energy was approximately 5,200 larger than the prevalence un-smooth production of breast milk in the group that the consumption of energy is enough.

The respondents' proportion that the protein consumption sufficient and breastmilk production were not smooth as many as 30 people $(62.5 \%)$ was larger than the breastmilk production smoothly as many as 18 people (37.5).

\section{DISCUSSION}

\section{Relationship between fluid intake and milk production}

Based on the research results obtained by the relationship significantly between the intake of fluids to the production of breast milk. Breastfeeding mothers are encouraged to drink $3000 \mathrm{ml}$ of water per day according to the frequency of breastfeeding their babies because after breastfeeding the mother will feel hungry. As the previous study said that mothers are encouraged to drink each time they breastfeed and consume an additional 500 calories per day 
(Kemenkes RI, 2013; Bardosono et al., 2016)

Data shown above implies that from 30 respondents who experienced breast milk production is not smooth; four respondents consume more than 12 cups (one cup $=250 \mathrm{ml}$ ) per day. It also concluded 26 respondents rest consumes less than 12 cups (less than $3000 \mathrm{ml}$ ) per day. After giving birth, the mothers' fluid consumption, especially when breastfeeding is applied, influenced milk production. Fluid intake is a factor that influences the production of breast milk during the administration of breastfeeding, because when the liquid in the mother enough, it will result in the production of milk quite well.

The study is in line with the survey results earlier, which stated that the intake of fluids is a variable related to breast milk production in the mother post section caesarean. The fluid consumption is an essential factor that affects physical growth; both in the fetus and the mother were pregnant. Not only during pregnancy, but during lactation was also the mother still requiring a liquid; therefore, the process of breastmilk production can meet the needs of the baby (Zhou et al., 2019).

Breastfeeding mothers need to meet nutritional needs, including the need for nutrients and fluids useful for postpartum health. Apart from that, breastfeeding mothers also need energy reserves to meet milk production. The demands that can meet breastfeeding mothers' nutrition include consuming other food of approximately 500 calories per day. Foods with a balanced nutritional diet can also meet needs such as carbohydrates, protein, vitamins, fats and minerals and it is necessary to drink at least three litres every day(Kemenkes RI, 2013; Woolhouse et al., 2016; Amir and Sulastri, 2019).

The intake of food consumed by the mother during pregnancy and after childbirth, primarily while breastfeeding, influences milk production. Nutrition and fluids are factors that influence the production of breast milk during the exclusive breastfeeding period because if nutrition and maternal fluids are fulfilled, it will result in insufficient milk production (Nurliawati, 2010; Ares Segura, Arena Ansótegui and Marta Díaz-Gómez, 2016).

The intake of food consumed by the mother during pregnancy and after childbirth, mainly while breastfeeding, influences milk production. Nutrition and fluids are factors that influence the production of breast milk during the exclusive breastfeeding period because if nutrition and maternal aids are filled, it will result in insufficient milk production (Nurliawati, 2010; Bardosono et al., 2016).

Producing good breast milk, mothers need fulfilled food intake such as adequate amounts of calories, fat protein and vitamins and minerals. In addition, breastfeeding mothers are also advised to drink 8-12 glasses of water / day and increase it by 3000 ml / day (Kemenkes RI, 2013; Ares 
Segura, Arena Ansótegui and Marta Díaz-Gómez, 2016)

\section{Relationship Support Husband of Production ASI}

Support husband to the mother in success and provide food nutritionally balanced, giving spirit and motivation. Hence, the thing is to make the mother happy and unhappy. The oxytocin hormone comes from the back (posterior) of the pituitary gland. For instance, prolactin, oxytocin is generated when the tip of the nerves around the breasts are stimulated by suction. Babies will get inadequate milk if they rely on reflex prolactin alone. Both reflexes must run balanced. Reflex oxytocin is a reflex expense of milk in nature is more complicated than the reflex of prolactin. At the time of breastfeeding, hormone oxytocin will spur muscle contraction smooth on the alveoli walls and the duct wall thus the milk can come out (Kurniati, Marsinova Bakara and Susanti, 2019).

Some items of questions for all respondents explain the husbands' support. The data can elaborate that a husband who does not ever provide bleak food fruits, vegetables, and food more than 41 (85.4\%). Husbands often help mothers when breastfeeding their babies, for example, carrying and giving them to mothers to breastfeed as many as 38 (79\%). Husbands who encourage mothers always to breastfeed their babies are 37 (77.1\%). Husbands often help the mother do the house's work as much as $35(72.9 \%)$. And husbands who often help take care of babies, for example, bathe the babies as many as $17(35.4 \%)$.

Support and attendance husbands are essential for mothers to breastfeed to raise, trust, stabilize, and provide mothers' motivation to breastfeed. It is in line with research earlier that revealed that respondents who get the family's support in giving breastfed exclusively had the opportunity 166.67 times to provide breast milk solely compared with respondents who did not get the support of the family (Setyaningsih and Farapti, 2019).

Family support is the attitude, action, and acceptance of a family towards its members. Family Report: 23715-91898-5-ED Report was generated on Saturday, Feb 6, 2021, 05:34 AM Page 24 of 33 members perceive that supportive people are always ready to provide help and assistance if needed. Sources of support for families in which the family's support refers to the support that the family views as something that can be accessed or held for the family, but family members saw that the supporting people are always ready to provide help assistance if needed.

Support husband is a factor External most substantial influence on the success of breastfeeding exclusively. Breastfeeding mothers need support and assistance, both when starting and continuing breastfeeding for up to two years, namely support from family, especially husbands. Supports of 
another person or people nearby were very instrumental in the success or not of breastfeeding. Support husband and family are a tremendous influence; getting generous support that obtained for breastfeeding meal will increasingly large also the ability to survive to continue to breastfeed. Support provided by experienced people around or on a breastfeeding woman's advice by an expert can positively impact. Family support is an external factor that can influence the success of exclusive breastfeeding because this can give the mother confidence to be able to breastfeed until the baby is six months old (Jama et al., 2020)

The support given to mothers is one of the factors that can influence mothers in giving exclusive breastfeeding. Mothers who have positive thoughts will undoubtedly feel happy seeing their baby and then thinking about it with great affection, especially when the mother kisses and cuddles the baby. This phenomenon happens when the mother is in a calm state. It is The support from the environment around the mother to provide breast milk to her baby and the steadystate.

\section{Relations Exposure Information about Breastmilk Against Breast milk Production}

A mother has the essential duty to breastfeed a baby because it dramatically determines her baby's survival. Breast milk is the best food and is following the baby's growth. Giving milk to the baby has not been implemented with good; there are some problems in breastfeeding which are: the lack of mothers' knowledge about the benefits of breastfeeding, lack of support for the family, the lack of support personnel, and a lack of exposure to breast milk benefits, and many other problems.

From all the 48 respondents who collected data on information exposure about breast milk, there were $31(64.5 \%)$ respondents who did not get information about breastfeeding. Of the 17 (35.5\%) respondents who never obtain information about breastfeeding, there were 7 (14.5\%) who received information about breastfeeding through television, and only 2 (28.6\%) of them had smooth breast milk production. Will but grades are still much lower than the number of mothers who experienced the smooth production of breast milk after getting information about breastfeeding from officers of health, i.e.as many as nine $(18.75 \%)$ of respondents.

A mother has the essential duty to breastfeed a baby because it dramatically determines her baby's survival. Breast milk is the best food and is following the baby's growth. Giving milk to the baby has not been implemented with good management. There are some problems in terms of breastfeeding, among others, due to lack of mothers' knowledge about the benefits of breastfeeding, lack of support for the family, the lack of support personnel health, and a lack of exposure to information about the 
benefits breast milk. Information exposure is the existence of media to obtain information and communicate about breastfeeding in printed media, electronic media, and online media to facilitate breastfeeding messages for the community. Information about breastfeeding, any press that consists the promotion and information about breastfeeding will increase the breastfeeding mothers' knowledge. Sufficient knowledge will raise the mother's confidence to breastfeed her baby (Harding et al., 2020).

Information about breastfeeding is a provision to mothers to prepare themselves in facing the future of lactation. Adequate knowledge will increase the sense of mothers' trust at the time of breastfeeding. A sense of confidence in yourself here will facilitate the production of breast milk. The information about the milk when breastfeeding on media and attendant health are also essential for the mother. If the mother already knows or understands breastfeeding, it will help the baby get breast milk exclusively (Akinyinka, 2016; Mundagowa et al., 2019).

Obstacles in giving exclusive breastfeeding identified by factors such as lack of information from the providers of care of health, lack of care follow- up at the beginning of the period after the childbirth, lack of support social that broad that cause stress in mothers postpartum and influence the production of breast milk. This study is in line with the results of previous studies which state that there is a significant relationship between exposure to information on exclusive breastfeeding and the behaviour of exclusive breastfeeding for six months.

\section{Relations intake supplements of Vitamin a Against Production of Breast milk}

The supplements intake, such as vitamin $\mathrm{A}$, has significant benefits for the mother and the baby during the postpartum period. At the time of the mother postpartum and the process of breastfeeding requires the intake of substances Report: 23715-91898-5-ED Report was generated on Saturday, Feb 6, 2021, 05:34 AM Page 27 of 33 of nutritional macro one of them vitamin A. Function vitamin $\mathrm{A}$ in the body to maintain a system of immunity of the body (immunity) and health to decrease the number of pain and the number of death. Vitamin A is contained in the mother's breast milk and becomes a primary source of babies' needs from zero months to infants aged two years. Postpartum mothers who consume a high intake of vitamin A will increase milk production. Functionality Award capsule of vitamin A dose high at the time of parturition are many unknown is to prevent VAD (Vitamin A deficiency) both in infants and the mother after childbirth(Sânzio Gurgel et al., 2017; Rahmadani et al., 2020)

It is necessary to give vitamin A to increase the amount of vitamin 
$A$ in breast milk during the puerperium. Vitamin $A$ is also beneficial to the baby. During the postpartum, a mother breastfeeds her baby; therefore, automatically baby gets the vitamin A. Benefits of vitamin $A$ and increasing the power hold the body may also improve the survival of children's lives. Vitamin A, which is given to the mother postpartum, is expected to meet vitamin A's needs either for mothers and babies. The baby will receive the contribution of vitamin A contained in breast milk. This study is in line with the results of previous studies which stated that vitamin A intake was significantly associated with breast milk production ( $\mathrm{p}$ $<0.05)$. The higher increase of vitamin A intake in the mother postpartum, the higher the breast milk production for infants. (Chahyanto and Roosita, 2014).

Vitamin A in breast milk is the primary source to meet infants' needs from the age of zero to the age of two. Postpartum mothers who consume a high intake of vitamin A can increase milk production. The function of giving high-dose vitamin A capsules during the puerperium is to prevent VAD (Vitamin A deficiency) both in infants and their mothers.

\section{Relations Intake Energy Against Breast milk Production.}

According to AKG 2013 recommending additional needs of energy mothers breastfeeding at six months of first postpartum amounted to $330 \mathrm{Cal}$ per day. Figures are relatively much smaller than the recommendation extra energy for mothers to breastfeed is $2250 \mathrm{Cal}$. The study is in line with the research results previously, which states a relationship between technique, frequency, duration of breastfeeding, and energy intake- a mother with heavyweight infants one to six months (Yanti, Yohanna and Nurida, 2018).

The intake of energy sufficient at the time of post giving birth helps the mother meet enough milk for her baby. This research found a number of the average consumption of carbohydrates derived from rice 137.6 grams per day, Tempe 3.65 grams per day, the bread of 10.29 grams per day and banana 6.39 grams per day. Intake of energy significantly affects pregnancy and breastfeeding mothers. The better the mother's energy intake, the more it will guarantee the quality and quantity of breast milk. Breast milk contains macronutrients and micronutrients. Macronutrients which consist of carbohydrates, fats, and proteins will be metabolized by the body to produce ATP (Adenosine triphosphate, which is an organic compound and hydrotrope that provides energy to drive many processes in living cells, e.g. muscle contraction, nerve impulse propagation, condensate dissolution, and chemical synthesis) and will be used for the needs of operations in the body. If the energy consumption is more than what the body needs, it will be stored in glycogen in the liver and muscles, 
affecting body weight (Williams et al., 2017).

If food that the mother consumes meets the body's energy needs, this energy can turn into the prolactin hormone to stimulate cells in the alveoli to produce breast milk (Sanima, Utami, N.W., 2017). In meeting the needs of energy, protein, vitamins and minerals, breastfeeding mothers need to consume more various foods because they are used for maintaining maternal health and milk production. What often happens is that many mothers want to lose weight immediately after giving birth. The mother does this condition by reducing her food intake while breastfeeding her baby (Kemenkes RI, 2017; Amir and Sulastri, 2019)

\section{CONCLUSION}

In this study, the Public Health Centre is expected to be more vigorous in giving consultation and enabling cadres to provide knowledge about breastfeeding to make promotion media enjoyable. The mothers who breastfeed to pay attention to all of the intakes that can increase breast milk production such as eating beans, spinach carrots, and others and the input of uid that is relatively greater equal to $3000 \mathrm{ml}$ per day. The husband is expected to provide support to the mother after childbirth. Both support the physical and psychological. The next research is expected to use glass measuring and food models catalogue.

\section{REFERENCES}

Akinyinka, M. (2016) 'Breastfeeding Knowledge and Practices among Mothers of Children under 2 Years of Age Living in a Military Barrack in Southwest Nigeria', International Journal of $M C H$ and AIDS (IJMA), 5(1), pp. 1-13. doi: 10.21106/ijma.79.

Amir, A. Y. and Sulastri, D. (2019) 'Hubungan Kadar Magnesium Dalam Asi Dan Asupan Energi Ibu Dengan Penambahan Berat Badan Bayi Usia 0-6 Bulan Dipuskesmas Lubuk Buaya Padang', Jurnal Ilmu Keperawatan dan Kebidanan, 10(1), p. 41. doi: 10.26751/jikk.v10i1.655.

Ares Segura, S., Arena Ansótegui, J. and Marta Díaz-Gómez, N. (2016) 'The importance of maternal nutrition during breastfeeding: Do breastfeeding mothers need nutritional supplements?', Anales de Pediatría (English Edition), 84(6), pp. 347.e1347.e7. doi: 10.1016/j.anpede. 2015.07 .03 5.

Bardosono, S. et al. (2016) 'Fluid intake of pregnant and breastfeeding women in Indonesia: A cross-sectional survey with a seven-day fluid specific record', Nutrients, 
8(11), pp. 1-11. doi: 10.3390/nu8110651.

Bogen, D. L. and Whalen, B. L. (2019) 'Breastmilk feeding for mothers and infants with opioid exposure: What is best?', Seminars in Fetal and Neonatal Medicine, 24(2), pp. 95-104. doi: 10.1016/j.siny.2019.01.001.

Chahyanto, B. A. and Roosita, K. (2014) 'Kaitan Asupan Vitamin a Dengan Produksi Air Susu Ibu (Asi) Pada Ibu Nifas', Jurnal Gizi dan Pangan, 8(2), p. 83. doi: 10.25182/jgp.2013.8.2.83-88.

Harding, K. et al. (2020) 'Breastfeed4Ghana: Design and evaluation of an innovative social media campaign', Maternal and Child Nutrition, 16(2), pp. 110. doi: 10.1111/mcn.12909.

Indonesian Ministry of Health (2013) 'Angka Kecukupan Gizi yang Dianjurkan Bagi Bangsa Indonesia', Jakarta, (mL), pp. 5-10.

Indonesian Ministry of Health (2017) Kualitas Manusia Ditentukan pada 1000 Hari Pertama Kehidupannya.

Indonesian Ministry of Health (2018) 'Hasil Utama Riset Kesehatan Dasar 2018', Kementrian Kesehatan Republik Indonesia. doi: 1 Desember 2013.

Jama, A. et al. (2020) 'Exclusive breastfeeding for the first six months of life and its associated factors among children age 6-24 months in
Burao district, Somaliland', International Breastfeeding Journal, 15(1), pp. 1-8. doi: 10.1186/s13006-020-0252-7.

Kurniati, Marsinova Bakara, D. and Susanti, E. (2019) 'The Effect Of Oxytocin Massage Method Using Lavender Essential Oils On The Smooth Production Of Breast Milk At Mother Postpartum In Rejang Lebong Regency', 14(Icihc 2018), pp. 91-94. doi: 10.2991/icihc-18.2019.23.

Mundagowa, P. T. et al. (2019) 'Determinants of exclusive breastfeeding among mothers of infants aged 6 to 12 months in Gwanda District, Zimbabwe', International Breastfeeding Journal, 14(1), pp. 1-8. doi: 10.1186/s13006019-0225-x.

Nurliawati, E. (2010) 'FaktorFaktor Yang Berhubungan Dengan Produksi Air Susu Ibu Pada Ibu Pasca Seksio Sesarea Di Wilayah Kota Dan Kabupaten Tasikmalaya'.

Rahmadani, P. A. et al. (2020) 'Asupan Vitamin a Dan Tingkat Kecemasan Merupakan Faktor Risiko Kecukupan Produksi Asi Pada Ibu Menyusui Bayi Usia 0-5 Bulan', Journal of Nutrition College, 9(1), pp. 44-53. doi: 10.14710/jnc.v9i1.26689.

Rahmayanti, H. D. S. A. (2018) 'Jurnal Fisika', 8(2), pp. 6877.

Riskesdas (2018) 'MAIN RESULTS OF RISKESDAS 
2018.'

Salamah, U. and Prasetya, P. H. (2019) 'Faktor-Faktor Yang Mempengaruhi Kegagalan Ibu Dalam Pemberian Asi Eksklusif', Jurnal Kebidanan Malahayati, 5(3), pp. 199204.

10.33024/jkm.v5i3.1418.

Sanima, Utami, N.W., dan L. (2017) 'Hubungan Pola Makan terhadap Produksi ASI pada Ibu Menyusui di Posyandu Mawar Kelurahan Tlogomas Kecamatan Lowokwaru Kota Malang', Nursing News, 3(2), pp. 155163.

Sânzio Gurgel, C. S. et al. (2017) 'Effect of routine prenatal supplementation on vitamin concentrations in maternal serum and breast milk', Nutrition, 33(July), pp. 261265. doi:

10.1016/j.nut.2016.06.015.

Senewe, M., Rompas, S. and Lolong, J. (2017) 'Analisis Faktor-Faktor Yang Berhubungan Dengan Kepatuhan Ibu Dalam Pemberian Imunisasi Dasar Di Puskesmas Tongkaina Kecamatan Bunaken Kota Madya Manado', Jurnal Keperawatan UNSRAT, 5(1), p. 109743.

Setyaningsih, F. T. E. and Farapti, F. (2019) 'Hubungan Kepercayaan dan Tradisi Keluarga pada Ibu Menyusui dengan Pemberian ASI Eksklusif di Kelurahan Sidotopo, Semampir, Jawa
Timur', Jurnal Biometrika dan Kependudukan, 7(2), p. 160. doi:

10.20473/jbk.v7i2.2018.160167.

Sirajuddin, Surmita and Astuti, T. (2018) Survey Konsumsi Pangan. Jakarta.

West Kalimantan, D. (2018) 'Recapitulation of infants aged 6 months to receive exclusive breastfeeding in the working area of the West Kalimantan Provincial Health Office in 2018'.

Williams, J. E. et al. (2017) 'Human milk microbial community structure is relatively stable and related to variations in macronutrient and micronutrient intakes in healthy lactating women', Journal of Nutrition, 147(9), pp. 1739-1748. doi: 10.3945/jn. 117.248864.

Woolhouse, H. et al. (2016) 'Maternal depressive symptoms at three months postpartum and breastfeeding rates at six months postpartum: Implications for primary care in a prospective cohort study of primiparous women in Australia', Women and Birth. doi: 10.1016/j.wombi.2016.05.00 8.

Yanti, H. F., Yohanna, W. S. and Nurida, E. (2018) 'Kelancaran Produksi ASI pada Ibu Post Partum Ditinjau dari Inisiasi Menyusu Dini dan Isapan Bayi', Jurnal Aisyah: Jurnal Ilmu 
314 The Indonesian Journal of Public Health, Vol 16, No 2 August 2021:297-314

Kesehatan, 3(1), pp. 39-46.

doi: 10.30604/jika.v3i1.74.

Zhou, Y. et al. (2019) 'Association between total water intake and dietary intake of pregnant and breastfeeding women in China: A cross-sectional survey', BMC Pregnancy and Childbirth, 19(1), pp. 1-10. doi: $\quad 10.1186 / \mathrm{s} 12884-019$ 2301-z. 